\title{
Reproductive Inequality in Canada
}

\author{
JEN RINALDI \\ University of Ontario Institute of Technology
}

\begin{abstract}
This article will examine the implications of taking an autonomy approach to reproductive health policy and practice, and the value of shifting to an equality approach. In legal terms, the acknowledgement that reproductive control is often a s. 15 equality matter, not simply a s. 7 concern, could lead to drastically different health care services. The author will begin by explaining $R$. $v$. Morgentaler (1988), the case which set the precedent that reproductive health is a s. 7 concern - that is, an autonomy matter. The author will identify some current conditions in the context of reproductive health in order to illustrate the shortcomings to s. 7. Specifically, she will demonstrate the importance that government take positive action rather than uphold a position of non-interference. The subsequent section will make a case for redressing present conditions via the invocation of s. 15 equality rights. The author will conclude with an evaluation of s. 15, considering the objection that not even this section can guarantee positive action.
\end{abstract}

Key words: reproductive autonomy, reproductive equality, Canadian Charter of Rights and Freedoms

\section{Introduction}

This article will examine the implications of taking an autonomy approach to reproductive health policy and practice, and the value of shifting to an equality approach. In legal terms, the acknowledgement that reproductive control is often a s. 15 equality matter, not simply a s. 7 concern, could lead to drastically different health care services. I will begin by explaining $R . v$. Morgentaler (1988), the case which set the precedent that reproductive health is a s. 7 concern - that is, an autonomy matter. I will identify some current conditions in 
the context of reproductive health in order to illustrate the shortcomings to s. 7 . Specifically, I will demonstrate the importance that government take positive action rather than uphold a position of non-interference. The subsequent section will make a case for redressing present conditions via the invocation of s. 15 equality rights. I will conclude with an evaluation of s. 15, considering the objection that not even this section can guarantee positive action.

\section{Autonomy Jurisprudence}

The following section will explain the landmark decision made in $R$. $v$. Morgentaler (1988), when legal reproductive autonomy was first established as an important precedent in Canadian law. My purpose here will be to mount the argument that s. 7 is grounded in a concept of personal autonomy-one which requires non-interference in order to be realized. In this case, Drs. Henry Morgentaler, Leslie Frank Smoling, and Robert Scott were charged with illegally inducing miscarriages at a Toronto clinic, thus violating s. 251(4) in the Criminal Code. Under the Criminal Code, abortion was considered an indictable offense unless it was performed in a hospital by a doctor, and was approved by a committee of physicians who determined that the medical treatment would serve the purpose of saving a pregnant woman's life. Initially, the appellants argued that the Criminal Code was "inconsistent with s. 1(b) of the Canadian Bill of Rights" (p. 3), but as their cases proceeded the Canadian Charter of Rights and Freedoms was introduced into Canadian jurisprudence. The Supreme Court 
considered whether s. 251 infringed on s. 2(a) freedom of conscience; s. 7 rights to life, liberty, and security of the person; and s. 12 right not to be subject to cruel and unusual punishment. The Supreme Court majority of 5 to 2 agreed that s. 251 infringed on women's s. 7 right, and the deprivation of this right was not in accordance with the principles of fundamental justice ${ }^{3}$. It was also determined that the violation did not satisfy s. 1 of the Charter ${ }^{4}$.

Introduced by then Justice Minister Pierre Elliot Trudeau in 1969, the amendment to the Criminal Code was progressive for its time, for it paved the way for the decriminalization of abortion. Previously an offense for which women could receive life imprisonment, abortion came to be legal as long as a committee comprised of at least three medical professionals could determine that the pregnant woman's physical, mental, or emotional health was endangered by the pregnancy: "[abortion was possible if] the continuation of the pregnancy of such female person would or would be likely to endanger her life or health". Morgentaler and his associates violated the Criminal Code by setting up "a clinic

\footnotetext{
${ }^{3}$ More broadly, s. 7 protects "the right to life, liberty, and security of the person and the right not to be deprived thereof except in accordance with the principles of fundamental justice".

${ }^{4}$ Cases alleging Charter violations undergo a two-step process. First, the Court determines whether a Charter right has been infringed upon. If this is the case, the next step is to determine whether this infringement can be saved by s. 1 of the Charter, which reads: "The Canadian Charter of Rights and Freedoms guarantees the rights and freedoms set out in it subject only to such reasonable limits prescribed by law as can be demonstrably justified in a free and democratic society".
} 
to perform abortions upon women who had not obtained a certificate from a therapeutic abortion committee of an accredited or approved hospital" (R. $v$. Morgentaler, 1988, p. 2-3). They did so because, as indicated by their public statements, they questioned "the wisdom of the abortion laws in Canada and [asserted] that a woman has an unfettered right to choose whether or not an abortion is appropriate in her individual circumstances" (p. 3).

Those in the Supreme Court majority wrote three different rulings; some of the rhetoric used in these rulings is pertinent to autonomy jurisprudence. Accompanied by J. Lamer, Chief Justice Dickson wrote that s. 251 "forces women to carry a fetus to term contrary to their own priorities and aspirations and which imposes serious delay causing increased physical and psychological trauma to those women who meet its criteria" (p. 63). This language invokes associations with autonomy theory. According to the liberal theories in which autonomy finds its home (Hobbes, 1985; Locke, 1980; Mill, 1978), the concept refers to self-rule or self-direction (autos—self; nomos_-government), whereby one makes personal, important decisions based on one's own values, principles, and purposes (Christman, 1991; Dworkin, 1988; Lukes, 1973).

Although C.J. Dickson cautioned against a broad application of s. 7 and the explicit connection with personal autonomy, security of the person can still be understood to have the power to protect reproductive autonomy. The Chief Justice also ruled that the criminalization of abortion ran contrary to women's 
priorities and aspirations, and so security of the person, even narrowly defined, refers to a corporeal autonomy the range of which extends to reproductive activities. McLeod (2002) discusses the effect of interference with reproductive autonomy: "if little respect is given to women's autonomy...they will lack control over how they reproduce or attempt to reproduce" (p. 2). She thus links autonomy with reproductive control. Indeed, reproductive decisions are necessarily grounded in women's bodies and reproductive capacities, and how freely made those decisions are has a tremendous effect on the physical and psychological hardship a woman might endure. Purdy (2006) explains the significance of ensuring women control their own bodies: "autonomy is particularly important for women...because reproduction still takes place in women's bodies, and because they are generally expected to take primary responsibility for child rearing” (p. 287). If a woman lacks access to abortion services, for instance, she must carry a pregnancy to term, resulting in a drastic transformation of her body and a lack of control over what happens to her body. She may also face psychological hardship, in that stigma is sometimes associated with pregnancy, and she will have to make potentially difficult, painful, lifealtering decisions regarding what happens after birth.

According to J. Wilson (who was in the majority but wrote one of the three separate majority rulings), s. 251 violated s. 7 rights to security of the person and liberty. She explained the violation of liberty in the following way: "Liberty 
in a free and democratic society does not require the state to approve the personal decisions made by its citizens; it does, however, require the state to respect them" (p. 167) $)^{5}$. She made explicit references to the concept of autonomy: "The right to 'liberty' contained in s. 7 guarantees to every individual a degree of personal autonomy over important decisions intimately affecting their private lives" (p.

37). For her, every right and freedom in the Charter is underpinned with the idea that "the state will respect choices made by individuals and, to the greatest extent possible, will avoid subordinating these choices to any one conception of the good life" (p. 37). That is, every right and freedom, including s. 7, to some degree is designed to respect autonomous decisions, as long as autonomy is understood as self-direction, the condition by which people make choices freely, unhampered.

\section{The Shortcomings to Reproductive Autonomy Rights}

While the 1988 Morgentaler case marks a historic victory for reproductive rights in Canada, current conditions and policies today make clear that not enough has been done to protect and facilitate reproductive rights. Gavigan (1992) argues that Canadian case law on reproductive rights is inconsistent with the rhetoric taken up by feminist movements:

The language of the Morgentaler judgments of the majority was a ringing restatement of an individual right to life, liberty, and security of the person and is thus consistent with the emphasis on

\footnotetext{
${ }^{5}$ Justice Wilson further argued that the decision to terminate a pregnancy was "essentially a moral decision, a matter of conscience" (p. 175) and thus s. 251 also violated the Charter's s. 2(a) freedom of conscience.
} 
abortion as a private and individual matter. While this reflects the language of lawyers and judges, it has not been the characterization of Canadian pro-choice and feminist activists, who have consistently framed abortion as an issue of equality and access (p. 222).

There are important implications to characterizing reproductive rights as individual rights. According to Dunsmuir's (1998) analysis of J. Wilson's decision: "the state is required only to respect such decisions [to terminate pregnancies], or to refrain from interfering with them, not to approve or facilitate them" (unpaginated). That is, in the case of reproductive rights, s. 7 protections cannot guarantee positive state obligations that would provide the resources women need in order to make reproductive choices. The protection of personal autonomy only requires that the state not interfere.

Indeed, despite the decriminalization and constitutional protection of abortion, access to abortion services in Canada continues to be limited. Granted, abortion is considered a medically necessary procedure by all provincial and territorial colleges of physicians and surgeons in Canada. Inasmuch as abortion is a medically necessary procedure, provinces and territories are bound by the Canada Health Act to provide free access to the service in order to qualify for their full federal funding for health care; however, federal governments have not taken measures to ensure that provinces and territories comply (Richer, 2008). The Liberal Independent Health Facilities Act (IHFA, 1990), originally 
introduced in order to enable governments to regulate and facilitate the delivery of health services, once gave preference to funding non-profit, Canadian-owned providers such as abortion clinics; but with the Conservative Bill 26, this preference in the IHFA was removed, leading to a redefining of medically necessary services and extra billing for those no longer deemed medically necessary (Gilmour, 2002). Says Gilmour:

The IHFA might have provided a framework for increased availability of and choice in abortion services. Owing to political pressures, fears of harassment and violence, limited resources and personnel, and disapproval or indifference, abortions are not available at many hospitals. Often a free-standing clinic is women's only option. While the statute could have been employed to facilitate the establishment of independent health facilities performing the procedure, it was not (p. 286).

With lack of regulation, abortion access varies according to the province or territory. Prince Edward Island lacks in-province abortion services, though women in the province can access funding for out-of-province services as long as they obtain a referral from their physician. New Brunswick only offers abortions in hospital settings and requires that the procedures are performed by gynecologists, in the first trimester of pregnancy (the first 12 weeks), only after two physicians have deemed the procedure medically necessary. Only British Columbia, Quebec, and Ontario provide abortions past 20 weeks of pregnancy. In these provinces, waiting lists are varied, and are especially long for women in rural areas. Prairie provinces typically offer services near the southern 
US/Canada border, requiring that some women travel vast distances; they only offer in-hospital services, and only during the first trimester (Dunn, 2008).

According to Gilmour, the Health Services Restructuring Committee (HSRC) poses another impediment to abortion access given its role in advising the Minister of Health on which hospitals to close due to funding concerns: "In some instances in Ontario, HSRC decisions resulted in the 'winning' hospitals (the survivors) being those with Roman Catholic affiliations" (p. 287). She cites the merger of Pembroke Civic Hospital with Roman Catholic Pembroke General, and the redirecting of funds from the closed Wellesley General Hospital to a still thriving Saint Michael's Hospital in Toronto. As a result, "access to a number of reproductive health care services previously available at the Wellesley [has been eliminated]" (p. 288), including birth control, sex education, and abortion services. Gilmour notes that decisions that favour Catholic hospitals in the restructuring of health care not only limit women's options, but also express a judgment about abortion that may be internalized:

[These institutional policies] carry with them an inherent judgment, the judgment of a publicly funded institution charged with carrying out government policy to provide comprehensive health care, that those seeking such services — primarily women — are also morally in the wrong, or at best misguided. That is not a silent presence but an active judgment with real consequences and ramifications ( $\mathrm{p}$. 288).

Further, the discrimination inherent in reproductive access has been studied in government-sponsored reports, most notably the Badgley Report 
(1977), commissioned before Morgentaler. The Badgley Report identified social barriers that particularly had an impact on "socially vulnerable women - the young, less well educated and newcomers to Canada" (unpaginated). Rodgers (2009), who has done extensive work mounting a defense of reproductive equality protections, explains that post-Morgentaler reports repeat the original findings in Badgley: "Thirty years after Badgley and twenty years after Morgentaler, ineffective and insufficient provision of abortion services continues to violate women's Charter equality protections" (p. 28). She describes these social barriers at length:

There was documentation of racist delivery of abortion and reproductive health care services and of imposed contraception and sterilization. The young, the poor, women with disabilities and aboriginal women, refugees and women of colour were noted as being particularly mistreated. There was documented evidence of pressure to terminate a pregnancy or to use permanent forms of contraception such as sterilization or Depo-Provera for some women $(2009$, p. 26).

It appears that even when reproductive services are available, the nature of the delivery of these services - be it racist, classist, ableist - has the potential to affect access. The racialized woman who feels pressure to terminate her pregnancy, the woman who cannot reach the only hospital in the area with the necessary services because she cannot afford the transportation or the time off work, the woman whose wheelchair cannot tackle the clinic stairs- these are the women whose access is compromised. 
Only in British Columbia do we see the limitation of political protests outside abortion clinics as well as abortion providers' offices and homes, according to the Access to Abortion Services Act (1996). Under s. 2 of the Act, while people are within what is designated an access zone, they must refrain from, among other items, "physically [interfering] with or [attempting] to interfere with a service provider, a doctor who provides abortion services or a patient" as well as “[intimidating] or [attempting] to intimidate a service provider, a doctor who provides abortion services or a patient". Graphic recordings and harassment are prohibited, under ss. 3 and 4, respectively. What is the value of access zones? Firstly, having zones may mitigate violence. Dr. Morgentaler's Toronto clinic was firebombed in 1992; there have also been three shootings (British Columbia 1994, Ontario 1995, and Manitoba 1997) targeting abortion service providers (CBC News, 2009). Further, harassment and intimidation, even when they do not escalate to violence, serve the function of alienating those involved in abortion provisions. Physicians may be frightened away from practicing the profession, leading to fewer services available to women; and women arriving at clinics already forced to make a difficult decision and undergo a difficult treatment may be made to feel guilt or fear. Gavigan (2009) explains that those responsible for fear tactics are driven ideologically to limit abortion access, for ideology around fetal rights and irresponsible pregnant women has thrived in Canada despite lacking any legal grounding, and this ideology has the power to limit access in 
ways that even the law has struggled to counter: "what is striking is that this campaign has been so successful without significant support in Canadian law" ( $p$. 132).

\section{A Case for Reproductive Equality}

Morgentaler and similar subsequent cases have missed a crucial detail: women's inequality has throughout history been rooted in who controls their reproductive abilities: "Reproductive autonomy is key to women's equality and essential to women's full and constitutionally protected membership in the Canadian state" (Rodgers, 2006, p. 1). If autonomy and equality are inseparable with respect to reproduction, then lack of autonomy, lack of control over their reproductive capacities, might help explain women's experiences of historical inequality. Colker (1992) elaborates: "It is because women are saddled with virtually all of the expenses of pregnancy and childbirth, as well as the costs of childcare, that we must insist that women be allowed to choose the conditions under which they become pregnant" (p. 85). Women have been historically disadvantaged by socially produced responsibilities associated with pregnancy and parenting. They have lacked control over their reproductive capacities due to policies and practices that reflected a lack of respect for the marginalized group they constitute.

In legal terms, women might be better served if reproductive rights were also grounded in the s. 15 right to equality. Under s. 15: 
15(1) Every individual is equal before and under the law and has the right to the equal protection and equal benefit of the law without discrimination and, in particular, without discrimination based on race, national or ethnic origin, colour, religion, sex, age or mental or physical disability.

(2) Subsection (1) does not preclude any law, program or activity that has as its object the amelioration of conditions of disadvantaged individuals or groups including those that are disadvantaged because of race...

Equality before or under the law means that Canadians are subject to the same entitlements. An individual or group is neither privileged nor disadvantaged in contrast with other Canadians as a result of laws that would unfairly discriminate on the basis of the identity characteristics identified or read into the section. Section 15(1) protects Canadians from unjustly discriminatory laws and ensures Canadians are all entitled to the same beneficial results of these laws. Subsection 2 ensures that it is possible to design laws that benefit an already disadvantaged group so that conditions that prevent people from enjoying the protections and benefits enjoyed by other society members may be redressed.

In a watershed case that interpreted s. 15(1), Andrews v. Law Society of British Columbia (1989) ${ }^{6}$, it was acknowledged by the Court that "every difference in treatment between individuals under the law will not necessarily result in inequality and, as well, that identical treatment may frequently produce

\footnotetext{
${ }^{6}$ In Andrews v. Law Society of British Columbia (1989), Mark David Andrews, a British citizen and permanent resident in Canada, argued against citizenship as a requirement for qualification for the provincial bar. The Supreme Court ruled that s. 15(1) had been violated but that the law was saved by s. 1 .
} 
serious inequality" (p. 25). The Court rejected the 'similarly situated' test used in Bliss v. Canada (Attorney General) (1979) ${ }^{7}$, a test which parroted the Aristotelian principle of formal equality such that law was applied to both men and women in the same manner regardless of the material differences between the sexes. In its place, the Andrews test was developed in order to identify s. 15 violations. The test asked whether the law made a distinction based on the enumerated and analogous characteristics protected under s. 15; and whether the distinction resulted in discrimination. Justice McIntyre defined discrimination in the following way:

"A distinction...which has the effect of imposing burdens, obligations, or disadvantages on such individual or group not imposed upon others, or which withholds or limits access to opportunities, benefits, and advantages available to other members of society" (p. 34).

Andrews marked a shift in Canadian jurisprudence with respect to the principle of equality. Acknowledging the problems inherent in formal equality, the Supreme Court began to determine inequality on the basis of discrimination instead of merely differential treatment.

\footnotetext{
${ }^{7}$ Stella Bliss left work abruptly due to her pregnancy (she gave birth four days later), then applied for unemployment insurance six days after giving birth. Her claim was denied because she did not meet the qualifying condition in sections 46 and 30 of the Unemployment Insurance Act; that is, she had not completed ten weeks of insurable employment. She had to wait six weeks before she was entitled to insurance. Bliss argued in Bliss v. Canada (Attorney General) (1979) that the Act violated s. 1(b) of the Bill of Rights. The Supreme Court ruled unanimously that the Bill's provision of equality before the law had not been violated.
} 
This concept, known theoretically as substantive equality, is endorsed often in feminist scholarship (Boyd and Sheehy, 1989; Colker, 1992; 2009; Porter, 2006; Pothier, 2006). Substantive equality involves the acknowledgement that resources and opportunities are not already distributed equally, and equal treatment thus sometimes entails treating groups differently in order to redress disadvantage. Minow's (1991) dilemma of difference may help clarify what this sort of equality is intended to redress: "The problems of inequality can be exacerbated both by treating members of minority groups the same as members of the majority and by treating the two groups differently" (p. 13). This kind of equality is only rendered meaningful if differences are respected, be they race, gender, class, or disability (Hughes, 1999). Differential treatment for the purpose of producing equality requires positive state action, rather than simply a position of non-interference.

In the case of reproductive health, s. 15 has the power to produce state obligations to regulate abortion provisions. Instead of merely protecting women's reproductive decisions from state interference, from overt legal coercion-as s. 7's right to security of the person can guarantee-s. 15 includes the state obligation to provide services and programs that would aim to correct historical disadvantage. Further, the principle ideally ensures that laws and policies are meaningful for all minorities that have been unduly discriminated against. Thus, securing s. 15 rights entails prohibiting treatment that would disadvantage 
minority groups. While the s. 7 right to security of the person, along with the principle of personal autonomy grounding s. 7, protects women's right to make decisions free from legal coercion, this right does not account for other factors that complicate or limit bodily control, such as prejudicial attitudes against women's intersecting identity characteristics. Such a problem could be redressed by invoking s. 15 .

Equality considerations in the matter of reproductive health would ideally shift policy focus away from a citizen's negative rights toward the state's positive obligations. Stricter guidelines on regulation of service in the Canada Health Act would ensure that more conservative provincial governments are not implementing administrative strategies to limit abortion access despite abortion being a legal right. The racist, classist, or ableist delivery of services would be subject to legal review because they function to limit reproductive access, and the poor distribution of a service is an equality matter. Along the same lines, feminist equality theorists like Young (2000) account for how structural inequalities are made manifest in violence; violence limits a citizen's full participation and inclusion in a community through fear, intimidation, pain, and trauma. Violence in the form of clinic bombings and attacks against abortion providers use these same tools to limit women's access to reproductive services.

Why has the Court system remained largely silent on reproductive equality, then? Or, in Rodgers's words: "If reproductive rights are a key location 
of women's social inequality, what accounts for the persistent refusal of the Court actively to consider the implications for women's equality?” (2006, p. 18).

Attempts have been made, so far in vain, to ground reproductive rights in the s. 15 right to equality. In Doe et al. v. The Government of Manitoba (2004), denied or limited access to safe and timely abortions was found to violate both s. 7 and s. 15 (as well as s. 2(a) freedom of conscience) of the Charter, though this judgment has been set aside and the decision has not served as a precedent for subsequent cases pertaining to reproductive rights (Richer, 2008). Morgentaler argues in his most recent case (Morgentaler v. New Brunswick, 2008) that New Brunswick's Medical Services Payment Act violates s. 7 and s. 15 by excluding abortions performed in clinics from its definition of entitled services, but the case has not yet proceeded (Richer, 2008). Inroads have been made, but there is more to be done.

\section{Is Equality Enough?}

Contained within s. 15 is the promise for positive action-a promise s. 7 cannot provide - although s. 15 too has shortcomings; of relevance here, state obligation for positive action remains vague. Indeed, Porter (1998) questions whether Andrews did enough to move away from formal equality, noting that no framework was established for positive action:

Such an approach [in Andrews] may ensure that positive measures addressing particular needs arising from disability, pregnancy or systemic discrimination will not be found to be discriminatory, but 
does not establish the framework for establishing when such positive measures are required. There is a significant further step involved between rejecting a 'same treatment' model of equality and accepting needs arising from the distinctive or pressing needs of disadvantaged groups protected by section 15 (p. 73).

In his review of case law after Andrews, he demonstrates that "the relatively open-ended comments in Schachter and $\mathrm{Haig}^{8}$ with respect to the broader ambit of positive obligations were replaced by comments suggesting that the issue of positive obligations had somehow been decided in the negative" ( $p$. 74). As examples, he quotes J. L'Heureux-Dube in Thibaudeau v. Canada (1995) 9: "Although s. 15 of the Charter does not impose upon governments the obligation to take positive actions to remedy the symptoms of systemic inequality, it does require that the government not be the source of further inequality" (446); and C.J. Lamer in Egan v. Canada (1995) ${ }^{10}$ : "It is clear that Parliament does not

${ }^{8}$ In Schachter v. Canada (1992), Shalom Schachter challenged the Unemployment Insurance Act for denying paternity benefits to an adoptive parent on the basis that he was not available for work. The Court in this case reaffirmed that s. 15 entailed both negative and positive rights. The same interpretation of s. 15 was reiterated in Haig v. Canada (1993), which concerned Graham Haig's ineligibility to vote in the Charlottetown Accord due to his moving out of the province.

${ }^{9}$ In Thibaudeau, the Income Tax Act was challenged for requiring that alimony payments be included as a woman's taxable income. The Court determined that that the Act was not in violation of s. 15.

${ }^{10}$ In Egan, James Egan and John Norris Nesbit, who were in a long-term relationship, challenged the Old Age Security Act, which did not include spousal benefits for spouses of the same sex. Although their appeal was dismissed, this was a landmark case for establishing that sexual orientation was an analogous prohibitive ground for discrimination under s. 15. 
have any constitutional obligation to provide benefits" (see Brooks v. Canada Safeway Ltd., 1989; Schachter v. Canada, 1992). The concept of equality was to be substantiated, but the substance to this day remains vague. That is, the state allows for positive action to redress inequalities, but offers no framework that would ensure the state has positive obligations.

In Law v. Canada (Minister of Employment and Immigration) (1999) ${ }^{11}$, a further explanation of s. 15 was attempted, which, far from solved the problem, and only offered further complications: "to prevent the violation of essential human dignity and freedom through the imposition of disadvantage, stereotyping, or political or social prejudice” (p. 88). The term 'dignity' refers to an inalienable attribute to human beings, something worthy of esteem. Fredman describes dignity as "valuable in underscoring the role of equality in situations in which there is no obvious comparator, making it impossible to demonstrate the demand of formal equality" (2011, p. 22). The concept of human dignity may solve the problem of tricky comparisons, but it moves further away from the framework for positive action recommended by Porter. This standard was associated with freedom - the freedom to make decisions and determinations unburdened by legal constraints. Lawrence $(2003,2006)$ argues that the rhetoric of freedom found in

${ }^{11}$ In Law, 39-year-old widow Nancy Law challenged the Canada Pension Plan on the grounds that she was denied survivor benefits due to her age. The Court determined that there was no violation under s. 15. 
Law was used to the detriment of the larger scope that s. 15 was meant to encompass:

The Supreme Court has said that the interests protected by human dignity relate to the realization of personal autonomy and selfdetermination, self-respect, and physical and psychological integrity and empowerment. This statement of purpose tends to obscure the possibility that section 15 is meant to prevent the subordination of groups, whether through systemic or other forms of discrimination (2006, p. 117).

She goes on to critique the liberty paradigm: "it does not simply thwart the claims of equality seeking groups_-it actively retrenches societal mechanisms which serve to support inequalities, whilst detaching these inequalities from plausible claims of discrimination" (p. 132). Systemic disadvantages fall to the wayside because they cannot be accounted for with the language of personal autonomy used to articulate the human dignity standard.

This standard of human dignity was abandoned in later case law, when in R. v. $\operatorname{Kapp}^{12}$ (2008) the Supreme Court returned to the Andrews discrimination standard for determining inequality; although, the general concern around positive obligations persists. Justice Wilson's words in Morgentaler continue to ripple

\footnotetext{
${ }^{12}$ In this case, a communal fishing license was granted exclusively to Indigenous people; commercial, mainly non-Indigenous fishermen contested the license when they were arrested for fishing at a time prohibited by the license, and argued in Court that they were discriminated against on the basis of race. The Court ruled that the license was not a violation of equality rights because s. 15(2) enables governments to create programs that are meant to ameliorate situations for disadvantaged groups.
} 
through Canadian jurisprudence: she argued that underpinning all Charter rights is a call to respect liberty. As long as Courts remain preoccupied with honouring personal autonomy, they might well continue to interpret Charter applications broadly and negatively. However, this shortcoming does not belong to s. 15 alone, for the entire Charter may be read as a shield when it needs at times to be a sword. The application of s. 15 to reproductive health would at the very least facilitate conversation in the Court system about the interpretation of s. 15. That conversation would be of crucial importance given that legal decisions build upon previous decisions. The tools at our disposal may be blunt, but among them all an equality rights approach has already laid the groundwork for positive state action.

\section{Conclusion}

This article has sought to identify the implications of taking an autonomy approach to reproductive health. It has argued for positive state obligation, in other words, the active intervention of the state in order to redress social inequalities. Although s. 15 has yet to produce a framework that would ensure the state upholds its duties to act positively, according to the rhetoric s. 15 , equality is meant to be substantive in character. The application of $\mathrm{s} .15$ to reproductive health could not only lead to fairer reproductive access, but might also hold Canadian Courts more accountable to their claims about equality rights.

Morgentaler was the watershed moment for reproductive rights in Canada, and that achievement should be neither forgotten nor downplayed. Decades after 
the case, however, we face strikingly similar conditions that existed preMorgentaler: a country where abortion provisions continue to be unregulated and thus inconsistent; where access is complicated by insurance, distance, hospital closures, shootings, and the list goes on and on; where women's ability to carry out a difficult decision is limited, not legally, but by pro-life billboards on the highway and Catholic shame. We must consider the possibility that autonomy is not enough. That autonomy is not even possible if social inequality deprives women of the meaningful options necessary for exercising the right. Canada cannot rest its reproductive health law on Morgentaler alone. The application of equality rights would mark a positive step forward in the right direction.

\section{References}

Abortion rights: significant moments in Canada (2009). CBC News. Retrieved from: http://www.cbc.ca/news/canada/story/2009/01.13/f-abortion$\underline{\text { timeline.html }}$

Access to Abortion Services Act (1996), RSBC Ch. 1.

Andrews v. Law Society of British Columbia [1989] 1 S.C.R. 143.

Badgley, R.F. (chairman) (1977). Report of the Committee on the Operation of the Abortion Law (Badgley Report). Ottawa: Supply and Services Canada.

Bliss v. Canada (Attorney General), [1979] 1 S.C.R. 183.

Boyd, S. \& Sheehy, E. (1989). Feminism and the Law in Canada: Overview. In T. Caputo et al. (Eds.), Law and Society: A Critical Perspective (p. 1). Toronto: Harcourt Bruce Janovich. 
HEALTH TOMORROW, VOL. 1(2013).

Canadian Bill of Rights (1960), c. 44. C-12.3.

Canadian Charter of Rights and Freedoms (1982).

Christman, J. (1991). Liberalism and Individual Freedom. Ethics, 101(2), 343.

Colker, R. (1992). Abortion and Dialogue: Pro-Choice, Pro-Life, and American Law. Indianapolis: Indiana University Press.

Colker, R. (2009). When is Separate Unequal? A Disability Perspective. Cambridge: Cambridge University Press.

Criminal Code of Canada, R.S. (1985), c. C-46.

Doe et al. v. The Government of Manitoba MBQB 285 [2004] M.J. No. 456.

Dunn, S. (2009). Abortion in Canada: From Sea to Shining Sea. In Of What Difference? The 20th Anniversary of $R v$. Morgentaler: Reflections on the Judgment and Abortion in Canada Today. National Abortion Federation and Faculty of Law University of Toronto.

Dunsmuir, M. (1998). Abortion: Constitutional and Legal Developments, 8910E. Government of Canada, Law and Government Division.

Dworkin, G. (1988). The Theory and Practice of Autonomy. New York: Cambridge University Press.

Egan v. Canada [1995] 2 S.C.R. 513.

Fredman, S. (2011). Clarendon Law Series: Discrimination Law. Oxford: Oxford University Press.

Gavigan, S. (1992). Morgentaler and Beyond: The Legal Regulation of Reproduction. In J.Brodie, S. Gavigan, \& J. Jenson (Eds.), The Politics of Abortion: Representations of Women in Canada (p. 120). Toronto: Oxford University Press. 
Gavigan, S. (2009). Better Never Than Late, But Why? The Contradictory Relationship between Law and Abortion. In Of What Difference? The 20th Anniversary of $R v$. Morgentaler: Reflections on the Judgment and Abortion in Canada Today. National Abortion Federation and Faculty of Law University of Toronto.

Gilmour, J. (2002). Creeping Privatization in Health Care: Implications for Women as the State Redraws its Role. In B. Cossman \& J. Fudge (Eds.), Privatization, Law, and the Challenge to Feminism (p. 267). Toronto: University of Toronto Press.

Haig v. Canada [1993] 2 S.C.R. 995.

Hobbes, T. (1985). Leviathan. New York: Penguin Books.

Hughes et al. (2005). Love Labours Lost? Feminism, the Disabled People's Movement and an Ethic of Care. Sociology, 39(2), 259.

Independent Health Facilities Act R.S.O. 1990, Chapter I.3.

Lawrence, S. (2003). Harsh, Perhaps Even Misguided: Developments in Law 2002. Supreme Court Legal Review, 90, 23.

Lawrence, S. (2006). Choice, Equality and Tales of Racial Discrimination: Reading the Supreme Court on Section 15. In S. McIntyre \& S. Rodgers, Diminishing Returns: Inequality and the Canadian Charter of Rights and Freedoms (p. 115). Canada: LexisNexis Canada Inc.

Locke, J. (1980). Second Treatise of Government. Indianapolis: Hackett Publishing Company.

Lukes, S. (1973). Individualism. Oxford: Blackwell.

McLeod, C. (2002). Self-Trust and Reproductive Autonomy. Cambridge: The MIT Press.

Mill, J.S. (1978). On Liberty. Indianapolis: Hackett Publishing Company.

Minow, M. (1991). Making All the Difference: Inclusion, Exclusion and American Law. Cornell University Press. 
HEALTH TOMORROW, VOL. 1(2013).

Morgentaler v. New Brunswick, 2008 NBQB 258, [2008] N.B.J. No. 279.

Porter, B. (1998). Beyond Andrews: Substantive Equality and Positive Obligations after Eldridge and Vriend. Forum Constitutionnel, 9(3), 71.

Porter, B. (2006). Expectations of Equality. In S. McIntyre \& S. Rodgers, Diminishing Returns: Inequality and the Canadian Charter of Rights and Freedoms (p. 23). Canada: LexisNexis Canada Inc.

Pothier, D. (2006). Equality as a Comparative Concept: Mirror, Mirror on the Wall, What's the Fairest of Them All? In S. McIntyre \& S. Rodgers (Eds.), Diminishing Returns: Inequality and the Canadian Charter of Rights and Freedoms (p. 135). Canada: LexisNexis Canada Inc.

Purdy, L. (2006). Women's reproductive autonomy: medicalisation and beyond. Journal of Medical Ethics, 32, 287.

R. v. Kapp, [2008] 2 S.C.R. 483.

R. v. Morgentaler [1988] 1 S.C.R. 30.

Richer, K. (2008). Abortion in Canada: Twenty Years After R. V. Morgentaler, PRB 08-22E. The Parliament Information and Research Services of the Library of Parliament, Law and Government Division.

Rodgers, S. (2006). Women's Reproductive Equality and the Supreme Court of Canada Ottawa: University of Ottawa.

Rodgers, S. (2009). Law: Facilitating and Impeding Access. In Of What Difference? The 20th Anniversary of $R$ v. Morgentaler: Reflections on the Judgment and Abortion in Canada Today. National Abortion Federation and Faculty of Law University of Toronto.

Schachter v. Canada [1992] 2 S.C.R. 679.

Thibaudeau v. Canada [1995] 2 S.C.R. 627.

Young, I.M. (2000). Five Faces of Oppression. In M. Adams (Ed.), Readings for diversity and social justice (p. 35). New York: Routledge. 